\title{
Excellence in Agri-Marketing through National Agricultural Market (NAM) for Sustainability of Indian Farming Sector
}

\author{
Arcot Purna Prasad \\ Associate Professor, \\ Institute of Management Christ (Deemed to be) University \\ Dr. Chandrasekhar Rao. V. \\ Associate Professor, \\ Global Academy of Technology
}

\begin{abstract}
National Agricultural Market (NAM), the most needed e-platform for the integration of agricultural markets across India is considered as an appropriate solution to overcome the challenges and problems faced by the present stakeholders of the Agri-marketing system. Related issues like states fragmentation into multiple market areas monitored by APMCs, different and numerous levy structures, multiple licenses requirement for trading across different mandis, interventions of high net worth bidders in price-fixing, inadequate infrastructural facilities in reaching mandis and non-usage of e-bidding technology, problems of information dissemination causing asymmetry, lack of transparency in price discovery, high market charges, movement controls between state to state, etc are to be addressed on priority basis in order to benefit the farmers and other stakeholders of agri-marketing industry. The need for the effective unified system across the country combining all agri-marketing platforms both at State and National level is the need of the day and has been well understood by our Prime Minister of India, Sri Narendra Modi and his team. The initiative is taken to have a sustainable environment through National Agricultural Market, which was launched on April 14, 2016. This enables a better price to farmers on their produce $\&$ improves the efficiency of the supply chain. Sustainable development is one which meets the needs of the present without compromising the ability of future generations to meet their needs. In this paper, the authors have attempted to understand the National Agricultural Market's success as a means to sustainability in agri-marketing directly and Indian economy growth indirectly. This paper will be partly based on the theoretical concept \&somewhat empirical study that deals with the idea of National Agricultural Markets and its relevance in bringing sustainable development in agrimarketing. The theoretical part consists of a critical review of literature relevant to the concept of agricultural production, marketing and unified market system and concludes in an attempt at a more precise formulation of the idea. The empirical part of the study is based on questionnaires served to randomly select traders and farmers of Karnataka state where unified marketing system ReMS is implemented much earlier to NAM. The empirical part of the study is done to provide background information that makes it possible to discuss sustainable growth possibility in a practical context and should therefore not be seen as a direct attempt to confirm the theory. The research will enable a better understanding of NAM's effort in achieving excellence in agrimarketing and sustainability of farming.
\end{abstract}

Keywords: Rashtriya E-Market Services(ReMS), National Agricultural Market, Sustainability, Small Farmers Agribusiness Consortium (SFAC).

\section{INTRODUCTION}

Farmers are the people who grow crops, manage the land, and safeguard biodiversity along with feeding billions of people. To meet the global demand for food needs, especially the developing nations like India with the second-highest population, farmers need to increase the 
production rapidly to300\% with the same available cultivable land. India is the2nd largest country with 60.3 per cent of agricultural land, different climates and seasons to support the growth of various crops. India's population is projected to be 1.5 billion by 2030 calling for an annual food grain production of 342 million tonnes whereas the ratio of cultivable land to population is declining gradually and expects to reach up to $55 \%$ by the same time. Currently, agriculture in India, a backbone of the Indian economy, is contributing to nearly $14 \%$ of GDP and directly or indirectly providing $50 \%$ of total employment. The major problem in the Indian agricultural sector is fragmented landholding due to ancestral property shared by brothers then next-generation sharing the divided property and the chain continues to the future generations leading to a smallholding. Maximum percentage (nearly $75 \%$ to $80 \%$ ) of farming families in India holds either 2 to 3 acres of land or less than that. New technology implementation is cost-effective under extensive holdings and burden to small and marginal landholders and pushes them towards traditional farming methods leading to lesser yield levels. Unplanned cropping, repeated farming of only Minimum Support Price (MSP) supported crops which consume more water, excess chemical and fertilisers usage eroding soil fertility; water mismanagement is other problems making farmers have low yields. The other significant issues in production are timely inputs, quality seeds, and cash flow in the form of loans for meeting expenditure, unseasonal rains, and unavailability of right pesticides and labour leading to losing the right level of yield from the crop.

Ever since independence, both Central and State Governments have introduced beneficial schemes for the agricultural sector either as a part of five-year plans or direct policies and made agri production and marketing as ever essential objectives of Indian planning and strategy. Despite the procedures taken to safeguard agriculture and secure sustainable development a reality in the last few decades, small and marginal farmers are not much benefitted as most parts of India have subsistence agriculture. Improvement of the farming sector at all levels should be the prime focus of any policy decision and is essential for sustainable practices. All the stakeholders of the farming sector must work for the betterment of farmers, especially small and marginal farmers through efficient markets, collaborative research from industry and academia and dissemination of knowledge. The continuous focus on the age sector by the private sector and government through production-related benefits like MSPs, subsidies on seeds and fertilisers, disbursing loans to meet the expenditure, power and water arrangements are helping the farming sector to survive in this primary sector.

The other side of the coin to producing is the marketing of presented at the right price and time. Many studies in India have shown that far existing delivery systems of agricultural produce are not efficient in reaching the benefits of modern farm technology to all stakeholders. The timely and cost-effective delivery of agree outputs remains a dream despite the efforts of the corporate sector and the Government. The major problem in agri-marketing can be attributed to lack of market knowledge by farmers, unfavourable APMC rules and levies, lack of grading facilities and institutional finance. Problems like storage facilities, transportation facilities to regulated markets and high commissions to intermediaries are not supporting the development in agri-marketing raising questions on sustainable growth. Lack of proper marketing channels forces the farmers to distress sale with low income. Farmers, to get their produce to markets and receive the right price whenever they are willing to, they need to be equipped with up-to-date and transparent pricing information, develop wellfunctioningefficientmarkets\& sound infrastructure. In India, currently, there are different delivery channels at the local, regional, state and national levels that assist in agri-marketing. 
There are nearly 1700 and is spread across the country and are located in distant placemaking farmers carry their produce to the mandis with transportation difficulties. Co-operative marketing is the other channel where farmers form societies to sell their food collectively to get a better price. The primary channel contributing to agri-marketing is through Agriculture Produce Market Committees(APMC) framed by respective state governments with their rules and levies. In India 2,477 principal regulated markets and 4,843 sub-markets are part of these PMCs reflecting massive fragmentation with interstate and intra-state farm-price differences. APMC Act makes the first sale of agriculture produce outside the notified market yards as an illegal sale. APMCs charge a market fee benefitting farmers very little, and multiple licenses are required to trade in different and are within the same state. These APMC taxes and agents' fees differ from state to state and distort markets in the price-discovery process at the national level.

Changing needs of consumers, technology and rapid dynamism in markets mixed with diversity and complexity requires reforms to support direct marketing of agricultural produce to consumers. Fast-changing economic forces coupled with transformation are demanding a strong linkage between rural and urban markets enabling greater participation among all the stakeholders to bring transparent price discovery mechanism into the regulated market system. Bringing necessary reforms coupled with proper price discovery mechanism through the controlled market system, will help streamline and strengthen agricultural marketing. A policy with a broad-based approach to agrarian sustainability through is producing, and marketing is the solution to meet the demands of changing the environment that takes care of the problems of stakeholders. The approach should enable farmers to enrich with tools and information they need to grow crops and market their harvest. Policies supported by investments, innovations and incentives are required to achieve sustainability in agriculture, delivering increased production coupled with good returns. Sustainability is the process of maintaining high productivity indefinitely, by replacing resources with resources of equal or higher value without degrading or endangering natural biotic systems. The approach that has to be framed to deliver productivity and sustainability must also lead to an efficient market system to benefit farmers with a suitable price discovery mechanism.

Mr.NarendraDamodardasModi, the existing and $15^{\text {th }}$ Prime Minister of India has initiated many reforms to upgrade the position of India as a fast developing country. Several welfare schemes and policies were initiated to frame the Indian economy as a sustainable economy. Some of the initiatives like Make in India, Digital India, Clean India, Skill India, 100 Smart Cities and Startup India, Standup India, have changed the face of economic growth. One such initiative is to focus one unified market system which serves the objectives of price discovery and real-time price dissemination among the stakeholders of the agriculture-related system. The hurdles of APMC Act and multi-licensing system which were causing producers to lose the price benefit arising from demand in different places are to be curbed in order to have sustainable environment in agricultural sector and this was considered by the existing Indian Central Government and came out with the unified market system National Agricultural Market (NAM).

The e-National Agricultural Market (NAM) is a technology-enabled trading system at all regulated markets aiming to integrate APMCs (mandis) and other secondary markets at regional, state and national levels and is brought with the inspiration of the unified market system that is implemented in Karnataka state by existing Congress Government under the leadership of Chief Minister, Sri.Siddaramaiah.One of the major initiatives taken by the Karnataka government to bring out the changes in the agri-marketing sector is to establish the Rashtriya e-Market Services Limited (ReMS). It is formed for the benefit of farmers and traders as a joint venture between the Karnataka government and NCDEX Spot Exchange Limited, a 
professionally managed online commodity spot exchange. ReMS is a particular purpose vehicle and modern platform incorporated to bring in efficiency and transparency in the agricultural marketing system for price discovery to benefit farmers and other stakeholders by combining all APMC markets and warehouses in Karnataka state. Out of the 155 central market yards and 354 sub-yards in Karnataka state, a total of 105 markets spread across 27 districts had been brought under the UMP as of March 2016 with the single licensing system. The platform provides modern facilities for grading, dissemination of prices for different grades of the commodities in different market yards/sub-yards, weighing, warehousing, electronic auction (e-bidding) and borrowing (loans in addition to crop loan) based on warehouse receipts. The broader geographical scope has enabled public and private sector investment in marketing infrastructure development and is creating the farmers more choices to sell their produce at a better price with more number of traders and buyers participating. This single licensing system enabled the traders to participate in bidding at all APMCs in the state increasing competition and yielding better price to producers. Bidding can be done from different states resulting in transparent price discovery and real-time monitoring of prices across the country benefitting all the stakeholders.

The success of ReMS inspires them in Karnataka state, e-NAM an online portal for agricultural commodities trading was launched in April 2016 by Indian Prime Minister, Sri Narendra Modi, to bring out a unified market system across the country to enable the farmers and other stakeholders to benefit from the price discovery and price information dissemination. The scheme envisaged networking of a few selected markets to a standard electronic platform. The identified integrated regulated markets across the country will provide access to farmers and traders for purchasing\& selling of agri-commodities at optimal prices in a transparent manner across the country. The e-NAM has initially enabled farmers in Uttar Pradesh, Madhya Pradesh, Jharkhand, Himachal Pradesh, Gujarat, Telangana, Rajasthan and Haryana states to sell 25 commodities in 21 wholesale Mandis through the online system. This common e-market platform would be integrating 585 selected regulated wholesale markets in different countries and union territories. Small Farmers' Agriculture-Business Consortium (SFAC) is assigned the role of implementing the national e-platform in 3 phases covering 250, 200 and 135 mandis in 3 years. States and UTs to be part of the e-platform need to bring out prior policy reforms related to a single licensing system, single-point levy of market fee across the State and create a provision for e-bidding.The Agricommodities brought to the mandis linked to the National Agricultural Market are traded by grading done electronically. In ideal markets of this kind, traders and buyers from any place in the country will be able to bid for this assessed commodity which fetches reasonable price to the farmers through efficient price discovery mechanism. Even payments will be credited directly to the accounts of producers/farmers/sellers through an e-transfer device by integrating financial institutions with the NAM platform hoping to cover the delay procedure that takes place in APMC mandis. This e-market is expected to develop a comprehensive model facilitating the integration of markets across the country and other stakeholders like warehousing, banking, insurance, finance, promotion, etc. This unified model is expected to have an advantage over existing market models in bringing out transparency in pricing and demand, competition among the bidders, efficiency in price and market information dissemination, risk management procedures and ever dynamic price signals, etc.with e-portal helping buyers and sellers to participate in large number. Price pooling creates transparent and authentic information with real-time linking to a central database resulting information symmetry in the market and participation from stakeholders brings price discovery in a single platform. 


\section{REVIEW OF LITERATURE}

1. Sunita Solanki,\&Dr Sara Attari (2016), in their research paper 'Agricultural Marketing in India: Problems and Prospects', talked about the network of regulated markets in India and benefits through it. They said that most of the state governments and UT had enacted legislation to provide regulations of agricultural produce markets and 286 markets in 1950 have grown to 7566 by March 2006 in India. Apart from regulated markets, India has 21780 rural periodical markets, and 15 per cent of them function under the realm of regulations. They came out with the opinion that the advent of regulated markets has helped in mitigating the market handicaps of producers \& sellers. Their study came out with the idea that the agriculture sector needs well-functioning markets to drive growth, employment and economic prosperity in rural areas of India. To provide dynamism and efficiency into the existing regulated marketing system, infrastructural support should take place with significant investments for the development of post-harvest benefits. In the article, they mentioned about Department of Agriculture and Cooperation's legislation that focuses on the establishment of private markets/yards, direct purchase centres, consumer/farmers' markets for immediate sale and promotion of public-private partnership (PPP) in the management and development of agricultural markets in India. Articles cover the provision that has been made in the Act for constitution of state agricultural produce marketing Standards Bureau for the promotion of grading, standardisation and quality certification of agricultural produce.

\section{Dr R. Sivanesan (2014), in his research work titled 'Problems of Rural Market in India -An} Overview', attempted to study the problems of the rural market. Rural Markets are defined as those segments of the overall market of any economy, which are distinct from the other types of markets like the stock market, commodity markets or Labour economics. The so-called urban markets are crowded and saturated, and the share of agriculture in GDP (Gross Domestic Product) is going down, but India still lives in her villages. Such a potential market was being ignored by the corporate sector and small and medium industries. Hence it is proposed to study the potentiality and problems of the rural market with a particular reference to Indian Rural Market. The market scenario in rural areas today is changing very rapidly. Rural consumers demand branded products mainly because of an increase in disposable income and literacy level. Rural families do not like to cut their expenditure on weddings, pilgrimages, constructions and consumptions. Rural consumers have more aspirations; today, this segment of buyers consumes a large variety of products, both durable and non-durables and willing to pay the right price for the right products.

\section{Dr.G.Rajendran \&Mr.P.Karthikesan (2014), in their research paper ' Agricultural}

Marketing in India-An Overview', spoke about agri-marketing situation and dynamics of regulated markets. They opined that the marketing of agricultural commodities had been promoted through a network of regulated markets in India. Most state governments and UT administrations have enacted APMC act for the regulation of agricultural produce markets. Though the government regulations are for the improvement of the Agri sector, periodic rural markets in general and the tribal markets in particular, remained away from development either in infrastructure or technology implementation. The study opined that the necessary reforms, coupled with proper price discovery mechanism through the regulated market system, would help streamline and strengthen agricultural marketing. To avoid isolation of small and marginal farmers from the benefits of agricultural produce, they need to be integrated and informed with the market knowledge like fluctuations, demand and supply concepts which are the core of the economy. Marketing of agriculture can be made effective if it is looked at the collective and integrative efforts from all the stakeholders of the agri sector. 
4. In the article 'Problems and Prospects of Agricultural Marketing in India: An Overview', authors A. Vadivelu and B.R. Kiran mentioned about the agri-marketing and facilities available to farmers to sell the produced. They pointed out that the marketing of all farm products tends to be a complicated process. They felt that a suitable marketing system should be designed to give proper reward or return to the efforts of the tiller of the soil. In the article, they focused on the importance of market information as a means of increasing the efficiency of the marketing system and promoting improved price formation.

5. In the research article, 'Determinants of Farmers Perception towards Regulated Agricultural Markets in Salem District', by authors Shakeel-Ul-Rehman\& M. Selvaraj (2013), spoke about the regulated marketing system and perception of farmers on the procedures and benefits of markets. For the farmer, the strategic function of the marketing system is to offer him a convenient outlet for his produce at a remunerative price. The study tries to explore the perception of farmers on functional performance and physical performance of the regulated agricultural markets. The study came out with the contributions required towards enhancing the performance of regulated markets regarding infrastructural facilities and provision of modern amenities in the regulated markets. In authors' opinion, the government must also examine its policies and regulations to (or "intending to") strength the marketing network and ensure that prices are being determined on the competitive basis and markets are being manipulated.

6. In the research paper 'Agricultural Marketing in India', by C. Elamathi (2013) spoke about the prevailing agricultural marketing conditions in India. Various problems faced by farmers in selling their produce and marketing reforms that are required to bring change to meet the dynamic needs of the farmers and economy. She opined that numerous interconnected activities are involved in reaching the produce from farmers to consumers which include planning production, growing and harvesting, grading, packing, transport, storage, agro- and food processing, distribution, advertising and sale. The supply chain of such activities can take place with the exchange of information and suitable finance. Marketing systems are dynamic, involve continuous change and improvement, and they have to be customer-oriented and has to provide the farmer, transporter, trader, processor, etc. with a profit. The efficiency of the market comes through an understanding of buyer requirements, both regarding product and business conditions. Even the author quotes that sound marketing system is that where the producer is assured of a fair price for his produce, and this can happen only when intermediaries between the farmer and the consumer are very few in layers, storage facility, transport facilities and regular market information is provided to the farmer

7. Amrutha C.P (2009), in her doctoral thesis, 'Market Information System and its Application for Agricultural Commodities in Karnataka State - A Case of Onion', opined that market information is an essential facilitating function in the agricultural marketing system. It facilitates marketing decisions, regulates the competitive market process and simplifies marketing mechanisms. Market information is a means of increasing the efficiency of the marketing system and promoting improved price formation. It is crucial to the farmers to make informed decisions about what to grow when to harvest, to which market produce should be sent and whether to or not to store it. Improved information should enable traders to move their agricultural produce profitably from a surplus to a deficit market and to make decisions about the viability of carrying out storage where technically possible. 


\section{NEED FOR THE STUDY}

Sustainable development is one that meets the needs of the present without compromising the ability of future generations to meet their needs. Due to many problems, agricultural producing and marketing have become the primary priority to central, and state governments of India and governments have initiated reforms and shown significant focus on these problems through many policies and frameworks. NAM is one among them, which is a prime focus of $\mathrm{Mr}$ Modi's government to bring the sustainable environment in agri-marketing. NAM came into existence in April 2016 and still in the very nascent stage and need to create knowledge on benefits to stakeholders through NAM participation. There is a need for understanding the knowledge levels and benefits that will be realised by the farmers and the other stakeholders to further speedup the NAM implementation in all the notified mandis. The National Agricultural Market (NAM) platform initiated by the central government to integrate agricultural mandis across the country may face hurdles initially due to a lack of awareness and education among the farmers and other stakeholders. In this regard, this study is done by the authors taking Karnataka State's e-market method, ReMS, as the base to understand the benefits and implications in the minds of farmers and other stakeholders. The study helps to know the requirements to reach out the knowledge of NAM to beneficiaries.

\section{OBJECTIVES OF THE STUDY}

Based on the comprehensive analysis of existing marketing and trade system, current policies and experience of implementation of ReMSduring the past two years, the present study is aimed to come out with knowledge levels and requirements in NAM implementation across the country. The main focus of the research is

$>$ To understand the efficiency and role of the e-marketing system (NAM) in creating the benefits to stakeholders in general and farmers in specific.

$>$ To know the benefits and knowledge levels of the farmers participating in ReMS, the initiative of the Government of Karnataka in improving the sustainable growth of the Agri sector.

\section{RESEARCH METHODOLOGY}

The study involves both Conceptual and Exploratory study. The conceptual research primarily focuses on existing agri markets and policies related to agricultural sectors and different initiatives taken by both the Government of India and Government of Karnataka. The exploratory focuses on identifying the requirements in information dissemination about National Agricultural Market and knowledge levels and expectations of primary stakeholders, i.e. farmers.

Data collection methods: The data collection will be from primary and secondary sources. Secondary data related to the different characteristics of the Agricultural Marketing agricultural commodities, initiatives of Central and State Governments to the sustainable development of the farming sector, etc.Is collected from various articles, government periodicals, journals and other secondary sources. Secondary data includes opinions of employees of State APMC Board, Research organisations and other such organisations related to agricultural marketing.

Primary data collected through structured questionnaires served to farmers, the primary stakeholders in agri-marketing.

Sampling Method: Stratified Random Sampling.

Sampling units: Farmers of Karnataka

Sample space: 150 farmers who are selling their produce to both APMCs and other channels. 


\section{ANALYSIS AND FINDINGS}

The questionnaire carries questions on primary risks faced by farmers in producing, pricing factors, crop selling centres, awareness on MSPs provided by Government of Karnataka, information on price dissemination projects, awareness on online marketing systems ReMS of Karnataka State initiation and \& e-NAM, the initiative of Central Government of India.

\section{Analysis and findings from data collected through the questionnaire served to 150 farmers}

1. Related to price information sources to farmers, respondents came out with choosing local traders, co-operative societies, and APMCs as primary information sources with equal weight. Other causes are co-farmers, newspaper, radio, television, agricultural extension staff, Kirana stores and agri-magazines have a good share in communicating the market value of maize to farmers.

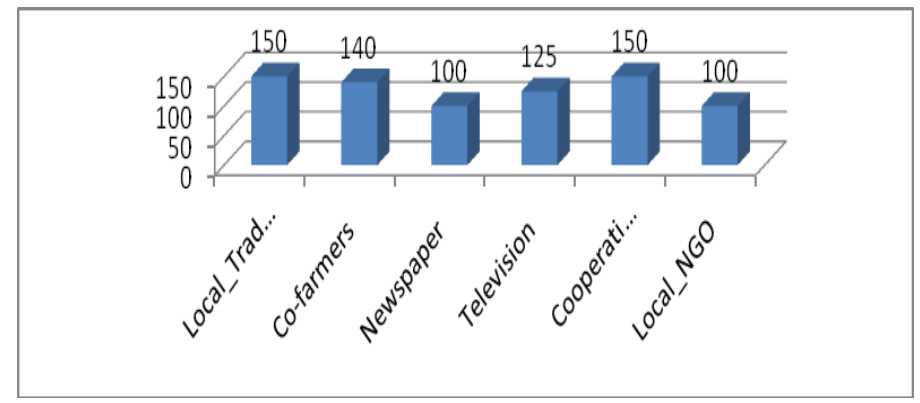

Fig 1:Sources of Information for farmers

2. Nearly 140 out of 150 farmers said that they are not aware of the information dissemination project taken by the Government of India and the methods followed by them in disseminating the prices of the commodities, training provided by the NCDEX as a partner to the government, APMC role and other things.

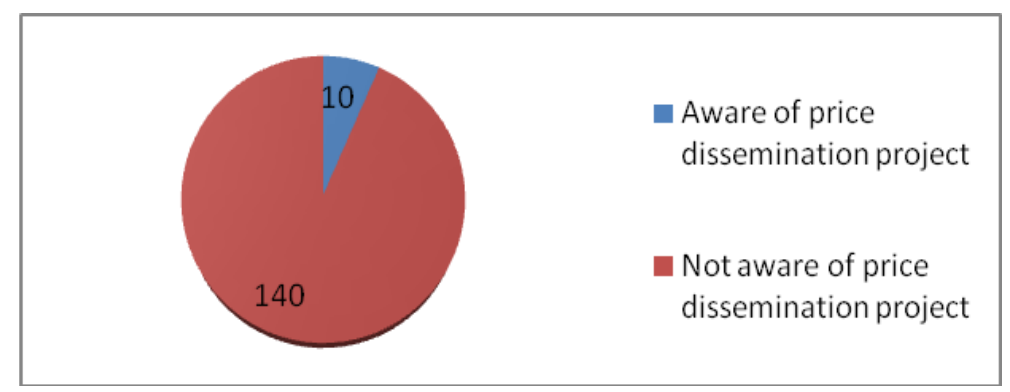

Fig 2: Awareness of price dissemination project to the farm sector

3. Few of the respondents are aware of price information dissemination through APMC ticker board's method, but all have given their negative opinion on display as ticker boards are presently not there in Davanagere, Chitradurga and Bellary market yards. But farmers can get the price information from the staff of APMCs. When farmers are attached with APMC market yards through registering their mobile number in APMC office, and cooperative societies, farmers can get prices in the original message in the form of letters to their registered mobiles. 
Table 1: Awareness of Services Provided by APMC

\begin{tabular}{|l|l|l|l|}
\hline \multicolumn{2}{|l|}{ Prices displayed on APMC ticker boards } & \multicolumn{3}{l|}{ Prices are shown in the native language } \\
\hline Yes & No & Yes & No \\
\hline 0 & 150 & 0 & 150 \\
\hline
\end{tabular}

4. When asked about the collective storage facility provided by APMC yards, farmers said they are aware of them but not utilising them. They keep the material under the custody of their yard registered brokers and sell the crop based on the price in the market. Most of them dispose of when the plant is brought to yards with prevailing rates, and very few take them back. As farmers have a fear of charges of storage and non-availability of sufficient warehouses, they do not use the collective storage facility. Other facilities like loading and unloading of the produce, facility to sell food when it is brought to APMC, and grading and weighing are known to the farmers, and they are utilising them.

Table 2: Awareness of services Provided by APMC

\begin{tabular}{|c|l|c|c|}
\hline Sl. No. & \multicolumn{1}{|c|}{ Particulars } & No. of Respondents & $\%$ of Respondents \\
\hline 1 & Facility for Sale of Produce & 140 & $93 \%$ \\
\hline 2 & Farmers Rest-house & 0 & $0 \%$ \\
\hline 3 & Loading and Unloading & 140 & $93 \%$ \\
\hline 4 & Weighment\& Grading & 120 & $80 \%$ \\
\hline 5 & Storage facility & 150 & $100 \%$ \\
\hline
\end{tabular}

5. When tried to collect the information about where the crop is sold, the majority $\left(2 / 3^{\mathrm{rd}}\right)$ of farmers told that they bring their harvest to the yards and sell as now transparency is there in buying and selling through brokerage charges are there. Nearly 55 farmers are selling to the local lenders and commission agents with whom farmers are in oral contract to deliver, and from whom loans and seeds are taken. Though procurement centres are there from government end, quality specifications of FCI and other matters related to payment are forcing farmers not to sell.

Fig 3: Percentage of crops sold by farmers

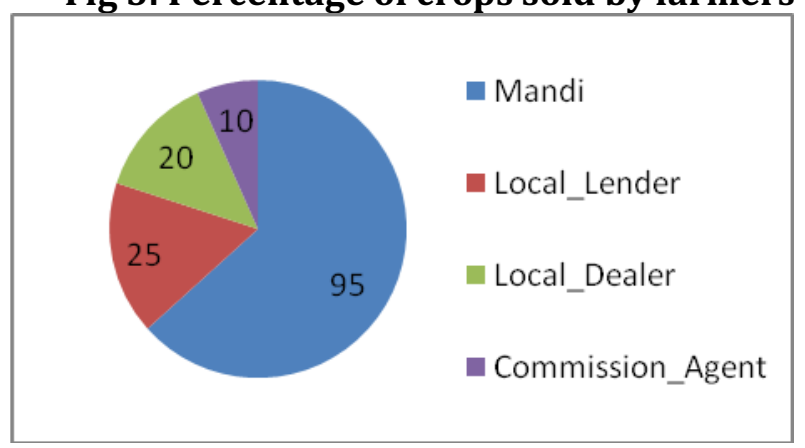

6. Awareness on minimum support prices announced by the Government of Karnataka is not impacting farmers' returns, though the knowledge is there in almost all farmers. The amount what farmers get majorly depend on quality aspects and the decision of traders supported by demand factors, the MSP is not a much-sought aspect by farmers. Except for 2 to 3 times, almost in all the years, farmers can realise the above MSP prices. 


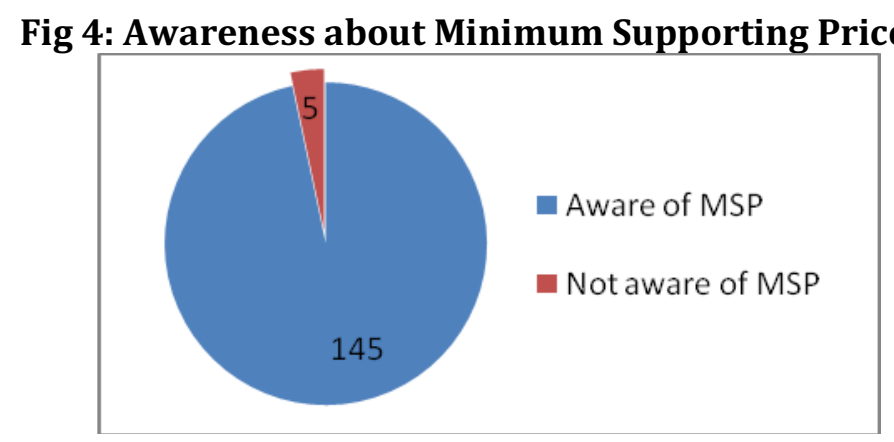

7. Virtually all farmer respondents are under the impression that Agri-marketing is not fetching the right price due to many reasons, and they go for immediate sale at the doorstep either through a contract made with the agent or loan provider before harvesting. It is distress sale leading to losing the excellent price for the produce. 93\% of Respondents feel that though they wait for for the better price to their crop, it is no guarantee that they get a reasonable price in the future. Next main reason to sell the product immediately is a lack of the storage facility (85\%) and charges that are to bear in storing them in warehouses. The other reasons being commission charges in mandis (49\%), distance to Mandi places(73\%), lack of knowledge of and procedures(55\%), membership charges, transportation problem(57\%) to reach Mandi and feeling that they would not get better price than what they arrive at their immediate disposal. The other reason that they do not show interest in bringing a product to yards is pricing based on quality $(60 \%)$ as they need to separate the produce based on the grading.

Table3: Response of Farmers regarding problems with agri-marketing

\begin{tabular}{|c|l|c|c|}
\hline Sl. No. & \multicolumn{1}{|c|}{ Particulars } & No. of Respondents & $\%$ of Respondents \\
\hline 1 & Lack of Storage facility & 128 & $85 \%$ \\
\hline 2 & Don't get Reasonable Price & 140 & $93 \%$ \\
\hline 3 & Quality-wise pricing of the product & 90 & $60 \%$ \\
\hline 4 & Lack of knowledge of Marketing & 83 & $55 \%$ \\
\hline 5 & The market is far away & 110 & $73 \%$ \\
\hline 6 & High Commission Charge & 73 & $49 \%$ \\
\hline 7 & Transportation Problem & 86 & $57 \%$ \\
\hline 8 & Delay in the sale at Mandi & 72 & $48 \%$ \\
\hline 9 & Delay in Payment & 92 & $61 \%$ \\
\hline
\end{tabular}

8. Awareness on Provisions created through ReMS in Karnataka state

Fig 5: Awareness ofReMS implementation:

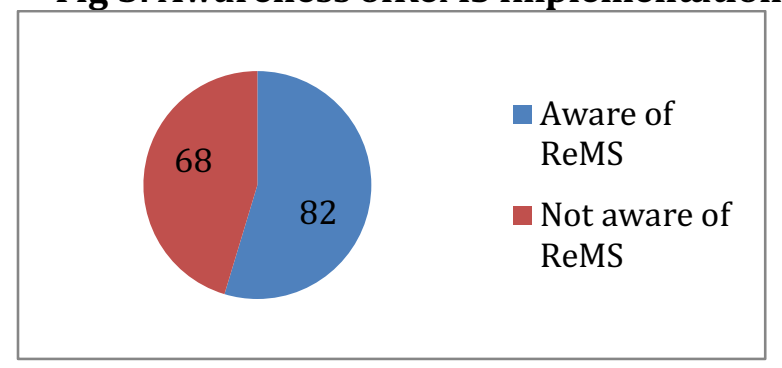

It is understood that 82 respondents (54\%) are aware of e-market system (Rashtriya e-Market Services) introduced by the Karnataka Government under Sri. Siddaramaiah and they are yet to explore the benefits through it. As all the market yards are not connected to e-market 
system, and with other reasons leading to distress sale, the awareness is to the extent of $50 \%$ only, indicating the need for awareness creation among all the farmers.

9. As the part of market reforms to bring efficiency \& transparency in the agricultural marketing system to have efficient price benefit and price discovery, which benefits farmers and other stakeholders of Agri commodity markets, Government of Karnataka has initiated ReMS, ane-Market system by using modern technology. From the inception of this unified market platform in 2013-14 to 2015-16, a more significant effort has been taken in creating awareness among the farmers, and it is targeted to have entire state coming under this unified system with 157 mandis and 11000 villages with knowledge. When asked the farmer respondents about the recognition of the centralised market system and its expected benefits, irrespective of the figures targeted, almost 50\% are lacking knowledge about the system and profits through the system. The percentage of respondents with an understanding of benefits is very less.

Table 4: Awareness of farmers on benefits through the implementation of ReMS

\begin{tabular}{|c|l|c|c|}
\hline $\begin{array}{c}\text { Sl. } \\
\text { No. }\end{array}$ & Particulars & $\begin{array}{c}\text { No. of } \\
\text { Respondents }\end{array}$ & $\begin{array}{c}\text { \% of } \\
\text { Respondents }\end{array}$ \\
\hline 1 & Electronic weighing and grading & 110 & $73 \%$ \\
\hline 2 & Ensures remunerative price & 98 & $65 \%$ \\
\hline 3 & Immediate credit of payment to the account & 90 & $60 \%$ \\
\hline 4 & Timely sale of products with good no. of bidders & 90 & $60 \%$ \\
\hline 5 & Transport facility to Mandi places & 20 & $13 \%$ \\
\hline 6 & Mandis under ReMS at nearby places & 68 & $45 \%$ \\
\hline 7 & Sale of the commodity through online bidding & 60 & $40 \%$ \\
\hline 8 & Scientific price discovery & 30 & $20 \%$ \\
\hline 9 & Single licence to sell across state mandis & 30 & $20 \%$ \\
\hline 10 & Provide market Infrastructure for storing & 30 & $20 \%$ \\
\hline 11 & Provide linkage to supply chain & 25 & $17 \%$ \\
\hline
\end{tabular}

10. When asked about the training needs on various aspects due to the lack of knowledge of the unified system, almost 93\% respondents came out with the opinion that ReMS should focus more on training and awareness creation methods to exploit the benefits of this system.

Table 5: Training needs on different aspects of Agricultural Marketing

\begin{tabular}{|c|l|c|c|}
\hline $\begin{array}{c}\text { Sl. } \\
\text { No. }\end{array}$ & \multicolumn{1}{|c|}{ Particulars } & $\begin{array}{c}\text { No. of } \\
\text { Respondents }\end{array}$ & $\begin{array}{c}\% \text { of } \\
\text { Respondents }\end{array}$ \\
\hline 1 & Warehousing\& warehousing receipt & 140 & $93 \%$ \\
\hline 2 & Grading and Certification & 95 & $63 \%$ \\
\hline 3 & Market Infrastructure and facilities & 140 & $93 \%$ \\
\hline 4 & Legal Reforms & 140 & $93 \%$ \\
\hline 5 & Marketing Information & 140 & $93 \%$ \\
\hline
\end{tabular}

\section{CONCLUSION}

NAM, a common electronic platform, much sought reform at this hour for sustainable development in the agricultural sector and in specific in the area of agri-marketing which has a role as equal as agri producing. This e-Market system allows farmers to sell their crops to buyers anywhere in the country with not incurring any additional expenditure. The benefits will be equal to all other stakeholders like large retailers, processors or exporters and consumers as they can log into this system from any Mandi in India connected to it this unified system. The system works by aggregation and assessing the produce in connected places. The 
inception of National Agricultural Market in India is a solution to the questions raised against the agricultural produce marketing committee reforms of 2013 implications. As of today in India, there are 6,500 APMC Mandis of which 585 large district-level mandis are expected to be linked by NAM. Though this unified e-market system is initiated with much hope and as many as 250 a remand is were supposed to have been linked to this financial year, only 21 markets in 8 states have been linked till now.

It is said that NAM is initiated with inspiration from ReMS, the e-Market unified system of Karnataka. It is launched in 2013-14 to bring the whole state into a single marketing system so that farmers of Karnataka will have the benefits of the best price for their produce. The indicators and volumes of sales through these reforms in Karnataka appear to be enhanced price discovery mechanism and benefits are said to be reaching farmers already. Computerised and mobile SMS bills along with the best value, are entering the farmers. As state like Andhra Pradesh has also connected with ReMS, greater competition and higher volumes are flowing to the markets with more e-bids. Awareness among farmers has said to be increased, and returns are said to be higher compared to previous years and in few centres the amount getting credited to accounts directly. Though the figures on benefits through ReMS are overwhelming, the study reveals a different scenario in awareness of farmers on this system and benefits arising are not known to almost $50 \%$ of farmers. The major problem is of training needs and education programs that are to be extensively taken to create awareness among all stakeholders, and it is mandatory as the attitude towards the unified market is negative in the minds of stakeholders like agents and business people. Training has to be taken on aggregation, quality standards, availability of assaying facilities, transparency in the price mechanism, price dissemination, and more number of bids from across the world, and so on. APMC mandis are to be given assurance of getting more income as delivery can happen from any APMC mandi. As NAM is based on the working style of ReMS, the basic requirements of ReMS are applicable and should occur through cooperation among all the States Agricultural Marketing Bards, procurement agencies and civil supplies corporations to ensure the proper functioning of a these-called unified system. This initiative is aimed at benefits to small and marginal farmers, and it serves the purpose when proper awareness among stakeholders \& infrastructure and cooperation from all state governments happen. Sustainable Development happens through Agri-marketing addressing the everyday needs through the unified market to increase agricultural output in an environmentally-sustainable, economically-feasible, and socially-responsible manner.

\section{References:}

Sunita Solanki,\&Dr Sara Attari (2016), 'Agricultural Marketing in India: Problems and Prospects', Imperial Journal of Interdisciplinary Research (IJIR), Vol-2, Issue-5, 2016, Pp 670-673.

Dr R. Sivanesan (2014),'Problems of Rural Market in India -An Overview', International Journal of Research in Business Studies and Management, Volume 1, Issue2, December 2014, PP 1-7

Dr.G.Rajendran\&Mr.P.Karthikesan,' Agricultural Marketing in India-An Overview', Asia Pacific Journal of Research Vol: I Issue XVII, September 2014, Pp159-164

Vadivelu and B.R. Kiran (2013), 'Problems and Prospects of Agricultural Marketing in India: An Overview', International Journal of Agricultural and Food Science 2013 3(3), Pp 108-118.

Shakeel, UI-Rehman and Selvaraj, M, 'Determinants of Farmers' Perception towards regulated Agricultural Market in Salem District', Life Science Journal, August 2013, Pp 2466-2474

C.Elamathi (2013), 'Agricultural Marketing in India', Perspex - Indian Journal of Research, Volume: 2, Issue:8, Aug 2013, Pp 45-47

Amrutha C.P (2009), 'Market Information System and its Application for Agricultural Commodities in Karnataka State - A Case of Onion, University of Agricultural Sciences, Dharwad'. 


\section{Author Name 1}

\section{BIOGRAPHICAL NOTES}

Arcot Purna Prasad is working as Associate Professor in Institute of Management, Christ University and has21 years of academic experience and pursuing his post-doctoral research in the area of FMCG Supply chains. His fields of research areas are Quality, Insurance and Lean processes. He authored four articles in international journals and presented his research papers at international and national conferences organised by prominent business schools. He has won prestigious awards for his contribution to the field of Management Education.

\section{Author Name 2}

Dr Chandrasekhar Rao. V, MBA, (PhD) is an Associate Professor working with Global Academy of Technology, Bangalore having experience of 7 years industry and 13 years in academics. His main areas of research are derivative markets and agri-markets. He is doing his doctoral research under Visvesvaraya University in the field of agro commodities. He has authored three articles in international journals on the agricultural problems and agriculture commodity derivatives related to chilli, cotton and maize. 